\title{
DiFFERENT FIELDS, SIMILAR LOCUSTS: ADAT COMMUNITIES AND THE VILLAGE LAW OF 1979 IN INDONESIA
}

\author{
Tsuyoshi Kato
}

\section{Introduction}

On December 1st of 1979 President Suharto signed legislation under the name of "Undang-undang No. 5 Tahun 1979 tentang Pemerintahan Desa" or "Law No. 5 of 1979 on Village Administration." The draft law had initially been introduced to the parliament (Dewan Perwakilan Rakyat or DPR) for deliberation in June of the same year and was ratified, with some revisions, in early October. ${ }^{1}$ The law is often referred to in English simply as the Village Law of $1979 .{ }^{2}$ Despite its seemingly innocuous title, the law, since its introduction, has been profoundly affecting the shape of Indonesian village administrative structure, this being especially the case outside Java. Yet, strangely, relatively little scholarly attention has been paid to it.

To appreciate the magnitude of administrative reorganization at the village level in recent years, let us examine Table 1. This shows the historical change in the number of administrative villages in Indonesia over the last thirty years. "Administrative villages" here signifies the lowest unit in the administrative hierarchy, which runs from the propinsi or provinsi (province), through the kabupaten (district), kecamatan (subdistrict), and village (now generally called desa or kelurahan). I was only able to secure figures on the number of villages for four of the years since Indonesia gained its independence. ${ }^{3}$

1 "Yang Berumah-tangga dan Tidak," Tempo, January 26, 1980, p. 40; C. S. T. Kansil, Desa Kita Dalam Peraturan Tata Pemerintahan Desa (Jakarta: Ghalia Indonesia, 1984), p. 19; "Village Admin Bill Likely to Be Ratified," The Indonesia Times, October 8, 1979, p. 1.

${ }^{2}$ See, for instance, Colin MacAndrews, "The Structure of Government in Indonesia" in Central Government and Local Development in Indonesia, ed. Colin MacAndrews, (Singapore: Oxford University Press, 1986 ), p. 21. ${ }^{3}$ Table 1 includes the administrative villages both in rural and urban areas. "NAV" in the table means "data not available" and "NAP" "not applicable due to political circumstances." The same abbreviations are also used in some of the other tables in this article. The totals for Indonesia in Table 1 exclude "NAV"and "NAP" in their calculation. The total for Indonesia in 1974 is different from the original; I adjusted it by keeping the figures for the provinces as they are in the original. A similar adjustment is also made for the 1974 data in 
Table 1: Historical Change in Number of Administrative Villages in Indonesian Provinces

Provinces

\begin{tabular}{|c|c|c|c|c|}
\hline & 1956 & 1961 & 1974 & 1986 \\
\hline Aceh & 568 & 572 & 708 & 5,567 \\
\hline North Sumatra & 2,517 & 2,573 & 5,729 & 5,643 \\
\hline West Sumatra & & 561 & 625 & 3,563 \\
\hline Riau & 1,252 & 637 & 725 & 1,103 \\
\hline Jambi & & 119 & 101 & 1,220 \\
\hline South Sumatra & & 824 & 429 & 2,432 \\
\hline Bengkulu & 575 & 55 & 70 & 1,226 \\
\hline Lampung & & 959 & 1,195 & 1,509 \\
\hline West Java & 3,802 & 3,794 & 3,870 & 6,980 \\
\hline Jakarta & 140 & 137 & 224 & 236 \\
\hline Central Java & 8,492 & 8,538 & 8,462 & 8,411 \\
\hline Yogyakarta & 407 & 554 & 556 & 556 \\
\hline East Java & 8,206 & 8,162 & 8,331 & 8,357 \\
\hline West Kalimantan & 4,060 & NAV & 4,993 & 4,690 \\
\hline Central Kalimantan & & 935 & 1,138 & 1,145 \\
\hline South Kalimantan & 1,507 & 602 & 676 & 2,369 \\
\hline East Kalimantan & 915 & 956 & 1,087 & 1,081 \\
\hline North Sulawesi & & 1,021 & 1,143 & 1,273 \\
\hline Central Sulawesi & & 1,089 & 1,260 & 1,305 \\
\hline Southeast Sulawesi & 7,144 & 606 & 403 & 694 \\
\hline South Sulawesi & & 3,422 & 1,165 & 1,209 \\
\hline Bali & & 574 & 557 & 608 \\
\hline West Nusa Tenggara & 5,982 & 469 & 564 & 564 \\
\hline East Nusa Tenggara & & 753 & 1,719 & 1,725 \\
\hline Maluku & 1,671 & 1,522 & 1,767 & 1,833 \\
\hline Irian Jaya & 67 & NAV & 2,634 & 897 \\
\hline East Timor & NAP & NAP & NAP & 1,753 \\
\hline Indonesia & 47,305 & 39,434 & 50,101 & 67,949 \\
\hline \multicolumn{5}{|c|}{$\begin{array}{l}\text { Sources: Statistical Pocket Book of Indonesia } 1957 \text { (Jakarta: Biro Pusat Statistik, } \\
\text { 1957), p. 36; Sensus Penduduk 1961: Penduduk Desa Jawa Buku III Propinsi Jawa } \\
\text { Timur (Yogyakarta: Pusat Penelitian dan Studi Kependudukan Universitas Gadja } \\
\text { Mada \& Biro Pusat Statistik, 1980), p. 795; Sensus Penduduk 1961: Penduduk Desa } \\
\text { Sumatra (Yogyakarta: PPSK UGM \& BPS, 1980), pp. 263, 264; Sensus Penduduk } \\
\text { 1961: Penduduk Desa Kalimantan (Yogyakarta: PPSK UGM \& BPS, 1980), p. 98; } \\
\text { Sensus Penduduk 1961: Penduduk Desa Bali dan Nusatenggara (Yogyakarta: PPSK } \\
\text { UGM \& BPS, 1980), p. 79; Peta Pembangunan Sosial Indonesia 1930-1978, SI 78-01 } \\
\text { (Jakarta: Biro Pusat Statistik, 1978), p. 9; Statistik Indonesia 1986 (Jakarta: Biro } \\
\text { Pusat Statistik, 1987), p. 7. }\end{array}$} \\
\hline
\end{tabular}

Number of Administrative Villages

1986

5,567

,563

1,103

1,220

, 432

1,226

236

357

4,690

1,145

2,369

1,305

694

64

725

897

1753

67,949 
Admittedly, these figures are not necessarily wholly reliable, but they should at least indicate general tendencies over the years. The table reveals that from 1956 to 1974 the overall increase in the number of administrative villages was slight, an increment of merely 5.9 percent. In contrast, a dramatic change took place between 1974 and 1986, with the number of administrative villages jumping 35.5 percent in this period. The total increase between 1956 and 1986 was 43.6 percent.

In the table we discern two different patterns of growth in the number of administrative villages. The pattern between 1956 and 1974 is mixed. Some provinces registered a considerable increase; some others witnessed a substantial decrease; yet others experienced no significant changes. The mixed pattern probably reflected trial-and-error implementations of administrative reorganization following Indonesia's independence. In contrast, the pattern of change after 1974 has been more or less consistent, with the single major exception of Irian Jaya, in that the number of administrative villages generally increased by leaps and bounds. This tendency seems to indicate concerted efforts on the government side, be it central or local, to increase the number of administrative units at the grass-roots level. Unfortunately I have no data at hand which can pinpoint when administrative villages began to multiply after 1974 . There is no doubt, however, that the Village Law of 1979 was a main factor in driving up their number, as will become clear in due course.

The Village Law of 1979

In his preface to the book Villages in Indonesia, Koentjaraningrat, the book's editor and renowned Indonesian anthropologist, writes: "Within the territorial confines of the Indonesian nation live people representing a wide variety of ethnic groups. ... But, just as there is ethnic diversity among her people, wide variety is also exhibited among her villages." 4 Indeed Batak huta, Minangkabau nagari, and South Sumatran marga, just to name a few examples from Sumatra, all have their distinct cultural underpinnings. And all of them serve, or rather used to serve, as local administrative units at the village level.

A well-known Indonesian proverb says "Lain padang, lain belalang; lain lubuk, lain ikannya" or "different fields, different locusts; different ponds, different fish." The proverb highlights the diversity of adat (customs and tradition) in Indonesia. Villages in the pre-1979 context, which were moulded to a great extent by local adat, also used to be diverse in their shape. One of the primary purposes of the Village Law of 1979 is precisely to replace this diversity with a greater uniformity or, to make an analogy to the above proverb, to produce clones of one type of locust in different fields. The multiplication of administrative villages between 1974 and 1986 implies that many of the former adat-cum-administrative villages, such as Minangkabau nagari, were broken up for this purpose.

The direct precursors of the Village Law are "Undang-undang No. 5 Tahun 1974 tentang Pokok-pokok Pemerintahan Daerah" (Law No. 5 of 1974 on Principles of Local

Table 6. There are additional data on the number of administrative villages from 1983 , but they are little different from the 1986 data. See Statistik Indonesia 1983 (Jakarta: Biro Pusat Statistik, 1984), p. 3.

${ }^{4}$ Koentjaraningrat, "Preface" in Villages in Indonesia, ed. Koentjaraningrat, (Ithaca, NY: Cornell University Press, 1967), p.v. 
Administration). and "Garis-Garis Besar Haluan Negara" or "GBHN" (the Broad Outlines of State Policy) of 1978. The former law aimed to standardize the form and functioning of local administration. Under letter " $\mathrm{c}$ " of Menimbang (To be Considered) it is stated: "in accordance with the nature of the Unitary State of the Republic of Indonesia, the state of affairs concerning Local Administration is to be made uniform as much as possible." 5 This" is to be accomplished within the framework of "real and responsible (local) autonomy [otonomi yang nyata dan bertanggung jawab]" whose purpose is to serve development or pembangunan. ${ }^{6}$ Law No. 5 of 1974, however, does not offer any concrete provisions for the lowest level of local administrative structure. Chapter $\mathrm{V}$ of the law does concern desa administration (pemerintahan desa), but it simply states that "Governing (pengaturan) of Desa Administration is to be determined by law."7

The need for legislating such a law on desa administration is specifically mentioned in the GBHN of 1978. Under letter " $\mathrm{f}$ " of Development Plans is stated as follows:

Strengthen desa administration so that [we will be] more competent to mobilize society in its participation in development and to run desa administration increasingly more extensively and efficiently. 8

The Village Law of 1979 thus is a culmination of the stipulations made in Law No. 5 of 1974 and the GBHN of 1978.

Law No 5 of 1974 and the Village Law superseded their predecessors on local and village administration, namely Undang-undang No. 18 Tahun 1965 tentang Pokok-pokok Pemerintahan Daerah (Law No. 18 of 1965 on Local Administration) and Undangundang No. 19 Tahun 1965 tentang Desapradja (Law No. 19 of 1965 on Village Government). ${ }^{9}$ Significantly, the latter laws were signed by then President Sukarno on September 1, 1965, effectively in the final month of his presidency. By replacing them with the new laws, President Suharto consolidated his hold over Indonesia's local administration under the New Order. It is an important part of innovations in the new laws to legislate the purge of either real or suspected participants in the G30S movement, the allegedly Communist-inspired coup of September 30,1965, from the existing as well as future local administration. 10

\footnotetext{
5K Wantjik Saleh, UU RI No. 5 Tahun 1979 tentang Pemerintahan Desa dan UU RI No. 5 Tahun 1974 tentang Pokok-pokok Pemerintahan di Daerah (Jakarta: Ghalia Indonesia, 1980), p. 41.

${ }^{6}$ Ibid., pp. 69-72.

7lbid., p. 66

${ }^{8} \mathrm{My}$ translation from Indonesian. The GBHN of 1978 is contained in Ketetapan Majelis Permusyawaratan Rakyat Nomor IV/MPR/1978 tentang Garis-garis Besar Haluan Negara. See Himpunan KetetapanKetetapan MPR 1978 (Jakarta: Partjutan Tudjuh, 1978), pp. 73-127. The quoted passage of "2. Administrative Apparatus" is found under Bab IV Pola Umum Pelita Ketiga; D. Arah dan Kebijaksanaan Pembangunan Umum; Politik, Aparatus Pemerintah, Hukum, Penerangan dan Pers, Hubungan. It is noteworthy that the above passage does not exist in the corresponding section of the GBHN of 1973 . However, there is a passage referring to the need to reorganize local administration, which was later to be realized in the Law No. 5 of 1974 . See Ketetapan-Ketetapan Majelis Permusyawaratan Rakyat Republik Indonesia Tahun 1973 (Jakarta: Departemen Penerbitan Republik Indonesia, 1973), pp. 96-97.

${ }^{9}$ Concerning Law No. 18 of 1965 and Law No. 19 of 1965, see respectively C.S.T. Kansil, Pokok-pokok Pemerintahan di Daerah: Dilengkapi dengan Pemerintahan Desa dan Pembangunan Desa (Jakarta: Aksara Baru, 1985), pp. 74-103; and Bayu Surianingrat, Pemerintahan Administrasi Desa dan Kelurahan (Jakarta: Aksara Baru, 1985), pp. 295-316.

10Wantjik Saleh, UU RI No. 5 Tahun 1979, pp. 14, 46.
} 
The 1965 law on Village Government is in general more sensitive to local adat than the later Village Law. It, for example, allows the usage of the position title of desa government's head "according to local customs [menurut adat kebiasaan setempat]."11 In contrast, the Village Law of 1979 is explicit in its determination to achieve uniformity in the village administrative structure. Under letter " $b$ " of the Law, it is stated:

In accordance with the nature of the Unitary State of the Republic of Indonesia, the state of affairs concerning Desa administration is to be made uniform as much as possible, with due respect, for various local conditions of Desa and stipulations of adat istiadat [customs] still in existence, in order to strengthen Desa administration so that [we will be] more competent to mobilize society in its participation in development and to run Desa administration increasingly more extensively and efficiently. ${ }^{12}$

The above paragraph, which basically rephrases those passages I already quoted from Law No. 5 of 1974 and the GBHN of 1978, does mention "due respect" (mengindahkan) for local variations. Yet, it is clear that uniformity in administrative structure is a major objective of the law. This point is far more clearly asserted in the State Gazette No. 56 of 1979, titled "Explications Concerning the Law No. 5 of 1979 on Village Administration." After explaining how the previous laws on village administration were still influenced by regulations dating back to the Dutch colonial period, one section under "General [explications]" states:

The above-mentioned [prior] laws and legislations did not regulate Desa administration uniformly and failed to give desa society enough stimulation to grow toward the direction of dynamic progress. Consequently the contemporary Desa and Desa administration are still variegated in color and form, with different regions having their own [administrative] characteristics, which sometimes constitute obstacles for [desa administration's] intensive development and management in order to raise the desa society's standard of living. The present law aims to standardize the form and composition of Desa administration with such National characteristics that guarantee the materialization of Pancasila Democracy in real terms by channeling [desa] society's opinions through a body called Lembaga Musyawarah Desa. ${ }^{13}$

True to its professed aim, the Village Law stipulates concrete steps toward the standardization of village administrative structure. The term "village," for example, is standardized for the whole of Indonesia: "desa" for administrative villages in the rural areas

\footnotetext{
${ }^{11}$ Bayu Surianingrat, Pemerintahan Administrasi Desa, p. 301.

${ }^{12} \mathrm{My}$ translation from the Indonesian: "sesuai dengan sifat Negara Kesatuan Republik Indonesia maka kedudukan pemerintahan Desa sejauh mungkin diseragamkan, dengan mengindahkan keragaman keadaan Desa dan ketentuan adat-istiadat yang masih berlaku untuk memperkuat pemerintahan Desa agar makin mampu menggerakkan masyarakat dalam participasinya dalam pembangunan dan menyelenggarakan administrasi Desa yang kian meluas dan efektif." Sce Wantjik Salch, UU RI No. 5 Tahun 1979, p. 11.

${ }^{13} \mathrm{My}$ own translation from the Indonesian: "Peraturan perundang-undangan di atas ini tidak mengatur pemerintahan Desa secara seragam dan kurang memberikan dorongan kepada masyarakatnya untuk tumbuh ke arah kemajuan yang dinamis. Akibatnya Desa dan pemerintahan Desa yang ada sekarang ini bentuk dan coraknya masih beraneka ragam, masing-masing daerah memiliki ciri-cirinya sendiri, yang kadang-kadang merupakan hambatan untuk pembinaan dan pengendalian yang intensif gua peningkatan taraf hidup masyarakatnya. Undang-Undang ini mengarah pada penyerakaman bentuk dan susunan pemerintahan Desa dengan corak Nasional yang menjamin terwujudnya Demokrasi Pancasila secara nyata, dengan menyalurkan pendapat masyarakat dalam wadah yang disebut Lembaga Musyawarah Desa." See ibid., p. 26.
} 
and "kelurahan" for those in the towns and cities. The law also specifies the internal structure, functioning, and prerogatives of village government: the village head (kepala desa) and administrative machinery (perangkat desa) as the executive body, the Village Deliberation Council (Lembaga Musyawarah Desa or LMD) as the consultative or "legislative" body, and the dusun as the sub-administrative unit under the desa, with its heads kepala diusun, and so on. ${ }^{14}$ Though not stipulated in the Village Law, another important desa administrative body is a Lembaga Ketahanan Masyarakat Desa or LKMD (Desa Society's Resilience Council). LKMD is construed as a village cabinet whose main function is to assist the desa head in carrying out development planning and efforts. ${ }^{15}$

The model for the uniform village administrative structure apparently comes from the conception of pseudo-parliamentary democracy and Javanese culture. For instance LMD and LKMD are miniature replications of institutions associated with parliamentary democracy, and the terms "desa" and "kelurahan" are derived from Java. It is the latter characteristic of the Village Law which needs to be stressed here. A recent article in Far Eastern Economic Review points out: "The law [the Village Law] sought for the first time to use the Javanese concept of desa (village) to define an administrative unit."16 As shown in Table 1, the provinces of Central and East Java, the Javanese cultural heartlands, have experienced little fluctuation in the number of administrative villages since 1956, while many provinces in the rest of the country have undergone drastic administrative reorganizations. The contrast cannot necessarily be explained by demographic factors; for example, the average sizes per village in East and Central Java in 1985 are still very large in comparison to those in many other Indonesian provinces (Table 2). It appears in fact, that the Village Law was designed to "Javanize" the village structure in the rest of the Republic. This is conceded in a research report on desa administration written under the sponsorship of the Indonesian Ministry of Internal Affairs. It notes that Java and Madura were excluded from the research in January of 1988 because "the patterns of desa administration to be propagated by the Village Law of 1979 are derived from those practiced in the two islands." 17

Because of its far-reaching impact at the grass-roots level and because of the amount of administrative work involved in its implementation, the Village Law could not possibly be put immediately into practice. The sheer number of villages, 68,875 in 1979 according to one magazine article, ${ }^{18}$ and the geographical expanse of the island state militated against such an expectation. Moreover, in some regions, doubt concerning the viability of the new law, which seems to neglect local adat despite its avowed intention

\footnotetext{
${ }^{14}$ Ibid., pp. 13-18. The administrative machincry consists of the desa secretariat and dusun heads. The desa secretariat in turn consists of a desa secretary and heads of three to five different sections, namely, administrative affairs, development affairs, general affairs, and financial affairs. See C.S.T. Kansil, Kitab Undang Undang Pemerintahan Daerah (KUPD) (Jakarta: Bina Aksara, 1985), p. 320.

15Kansil, Pokok-pokok Pemerintahan, p. 346.; Kansil, Kitab Undang Undang, pp. 380, 393; I. Nyoman Beratha, Desa: Masyarakat Desa dan Pembangunan Desa (Jakarta: Ghalia Indonesia, 1982), pp. 148-49. LKMD used to be called Lembaga Sosial Desa or LSD (Desa Social Council); LSD was replaced by LKMD under Presidential Decree No 28 of 1980 (Keputusan Presiden Nomor 28 Tahun 1980 tentang Penyempurnaan dan Peningkatan Fungsi Lembaga Sosial Desa Menjadi Lembaga Ketahanan Masyarakat Desa). See Kansil, Pokok-pokok Pemerintahan, pp. 343-49.

16 "Debt drain on Development," Far Eastern Economic Review, March 3, 1988, p. 27.

${ }^{17}$ My translation. See "Pemerintahan Desa: Laporan Penelitian" (Jakarta: Badan Penelitian dan Pengembangan Departemen Dalam Negeri kerjasama dengan Yayasan Ilmu-ilmu Sosial, 1988) (unpublished research report), p. 2.

18"Yang Berumah-tangga dan Tidak," p. 40.
} 
Table 2: Historical Change in Average Population per Administrative Village in Indonesian Provinces

\begin{tabular}{|c|c|c|c|}
\hline Provinces & $\begin{array}{l}\text { Average } \\
1961\end{array}$ & $\begin{array}{c}\text { Population per Administrative } \\
1974\end{array}$ & $\begin{array}{r}\text { Village } \\
1985\end{array}$ \\
\hline Aceh & 2,802 & 3,092 & 535 \\
\hline North Sumatra & 1,849 & 1,236 & 1,674 \\
\hline West Sumatra & 4,024 & 4,720 & 1,029 \\
\hline Riau & 1,943 & 2,440 & 2,279 \\
\hline Jambi & 6,216 & 11,069 & 1,416 \\
\hline South Sumatra & 3,427 & 8,888 & 2,225 \\
\hline Bengkulu & 4,604 & 8,250 & 763 \\
\hline Lampung & 1,706 & 2,647 & 3,967 \\
\hline West Java & 4,598 & 5,820 & 4,403 \\
\hline Jakarta & 19,702 & 21,034 & 33,175 \\
\hline Central Java & 2,142 & 2,702 & 3,202 \\
\hline Yogyakarta & 4,027 & 4,639 & 5,336 \\
\hline East Java & 2,648 & 3,158 & 3,714 \\
\hline West Kalimantan & NAV & 444 & 600 \\
\hline Central Kalimantan & 529 & 679 & 995 \\
\hline South Kalimantan & 2,441 & 2,667 & 966 \\
\hline East Kalimantan & 552 & 733 & 1,422 \\
\hline North Sulawesi & 1,242 & 1,611 & 1,866 \\
\hline Central Sulawesi & 633 & 792 & 1,180 \\
\hline Southeast Sulawesi & 858 & 1,879 & 1,561 \\
\hline South Sulawesi & 1,260 & 4,607 & 5,459 \\
\hline Bali & 3,129 & 3,980 & 4,339 \\
\hline West Nusa Tenggara & 3,853 & 4,115 & 5,402 \\
\hline East Nusa Tenggara & 2,184 & 1,394 & 1,756 \\
\hline Maluku & 547 & 672 & 891 \\
\hline Irian Jaya & NAV & 382 & 1,513 \\
\hline East Timor & NAP & NAP & 356 \\
\hline Indonesia & 2,357 & 2,441 & 2,412 \\
\hline
\end{tabular}

Sources: For 1961 and 1974, the same sources as in Table 1; Penduduk Indonesia 1985 menurut Provinsi: Hasil Pendaftaran Rumah Tangga (Angka Sementara) Seri SUPAS 85 No. 3 (Jakarta: Biro Pusat Statistik, 1986), p. 6. 
to the contrary, was already raised before the law was even enacted, for example in West Sumatra and South Tapanuli. ${ }^{19}$

Kansil reports that 61,341 desa were registered by the Indonesian Ministry of Internal Affairs in 1979.20 This does not, however, necessarily prove that these villages were already functioning as the lowest administrative apparatus in that year. It is more likely that the pre-registration and enumeration of desa-to-be had already been under way while the Village Law was being deliberated in the Indonesian parliament. Take, for example, the case of West Sumatra. The Ministry of Internal Affairs' list cited by Kansil enumerated 3,516 desa in West Sumatra in 1979. Most probably this number simply refers to the jorong or korong, the sub-village units under the nagari, which were later equated in most cases with the dusun under the Village Law. Such a speculation is supported by the 1980 census returns for West Sumatra which I collected in Padang in 1982. The returns were sent by the kabupaten offices of Kantor Sensus dan Statistik (the Census and Statistics Bureau) to the provincial head office in Padang. Depending on the districts, the results were broken down by nagari, desa as well as nagari, or just desa. The confusion indicates that the desa were not yet properly recognized as the village administrative unit in West Sumatra, or at least the district offices lacked consensus about the matter.

As the first step toward the implementation of the Village Law, on February 6, 1980, the minister of internal affairs sent an Instruction No. 9 of 1980 to all the governors in Indonesia to the effect that they should brief local officials (e.g., bupati or district heads) on proper understanding of the Village Law. ${ }^{21}$ It was only on January 24, 1981 that the minister, through Regulation No. 4 of 1981, issued concrete directives concerning how to reorganize existing villages in order to create new desa. Among the important considerations in carrying out administrative reorganization to create new desa, were mentioned population size, territorial size, existence of sufficient communication/transportation facilities, etc. 22

Reportedly, implementation of the Village Law in many cases did not or could not take place in earnest until 1983.23 In West Sumatra, for example, the law was initially not well received, and many Minangkabau, especially adat experts, voiced their concern that the disappearance of nagari in the administrative structure would adversely affect the adat. As late as 1982, according to Imran Manan who conducted research in West Sumatra in that year, the implementation of the Village Law there was still at the level of pilot projects. ${ }^{24}$ To accommodate to the Minangkabau feeling toward adat, in late 1983 the provincial government of West Sumatra issued a Provincial Regulation No. 13 of 1983, in which the formation of KAN or Kerapatan Adat Nagari (Nagari Adat Councils) was

19 “Soal Politik Tak Usalah," Tempo, November 3, 1979, p. 22; "Demokatis, Tapi Berbau Feodal," ibid., November 17, 1979, p. 23.

20 Kansil, Desa Kita, p. 199.

${ }^{21}$ Kansil, Kitab Undang Undang, pp. 313-17.

22Ibid., pp. 337-43.

23 "Pemerintahan Desa," p. 22.

${ }^{24}$ Imran Manan, "A Traditional Elite in Continuity and Change: The Chiefs of the Matrilineal Lineages of the Minangkabau of West Sumatra, Indonesia" (PhD dissertation, Department of Anthropology, University of Illinois at Urbana-Champaign, 1984), p. 81. 
announced. 25 Members of the council would consist only of adat leaders. The KAN would maintain the right to decide on adat matters within the nagari, especially those concerning disputes on adat lands, even after the nagari was dissolved from the administrative structure.

No matter how awkward the process of implementing the 1979 Law might have been, the fact remains that it has been implemented in all of Indonesia for the last several years; not a mean feat for such a vast, insular, and populous state.

If properly implemented, the Village Law of 1979 will probably occasion profound changes in the countryside. One may ask how it has been affecting the lives of the rural populace in Indonesia thus far. Has it been merely a reshuffling and renaming of rural settlements or has it been more than that? I will address myself to these questions, mainly drawing upon my experience, though limited, in the province of Riau. Riau is particularly suited for considering this question: in 1976 it had already issued a provincial regulation akin to the Village Law of 1979.

I conducted research in the Kuantan area of Riau from November 26, 1984 to January 21,1985 . About one month of this period was spent in the village of Koto Dalam (pseudonym). For the rest of the time I traveled round Kuantan, talking to kecamatan (subdistrict) officials and local adat experts. The main purpose of my research was to gather information on a social history of this region and in particular to investigate socio-economic changes in Kuantan since the turn of the century. I also visited the whole of Kabupaten [district] Indragiri Hulu, which encompasses Kuantan, for two weeks in October of 1982, traveling extensively in the district. As is apparent from the above-mentioned research aims, they were not directed to investigating the Village Law of 1979, as such. Thus, this section of my article is based more on impressionistic observations than on detailed research on the topic.

\section{"Desa Multiplication" in Riau}

In many ways the province of Riau is a reflection of Indonesia, being diverse in terms of ecology, ethnicity, and culture. It is conventional to divide the province into two contrasting ecological regions of mainland Riau (Riau daratan) and island Riau (Riau kepulauan). A majority of Riau's inhabitants are classified as Melayu or Malay. In addition there are a substantial number of Minangkabau, Buginese, Banjarese, Javanese, Mandailing, and some suku terasing (isolated tribes) such as Talang Mamak, Sakai, and Akit. Some of them, for example the Minangkabau and Mandailing, have lived there for centuries, while others, such as Buginese and Javanese, are relatively recent migrants.

Part of Riau's cultural diversity is evinced by the variety of names applied to the village as the lowest unit in the administrative hierarchy of the province. In Riau the village used to be called by such varied local names as kewalian, kenegerian, kepenghuluan, and kampung, and its head, wali negeri, batin, penghulu, datuk kaya, or kepala kampung. Evidently the provincial government regarded this diversity as problematic from the administrative viewpoint. Accordingly, it tried to standardize the terminology, structure, and functioning of villages under its jurisdiction after its formal promulgation

25 Peraturan Daerah Propinsi Daerah Tingkat I Sumatera Barat Nomor 13 Tahun 1983 tentang Nagari Sebagai Kesatuan Masyarakat Hukum Adat dalam Propinsi Daerah Tingkat I Sumatera Barat (Padang: Biro Bina Pemerintahan Desa Kantor Gubernur KDH Tk. I Sumatera Barat, 1983). 


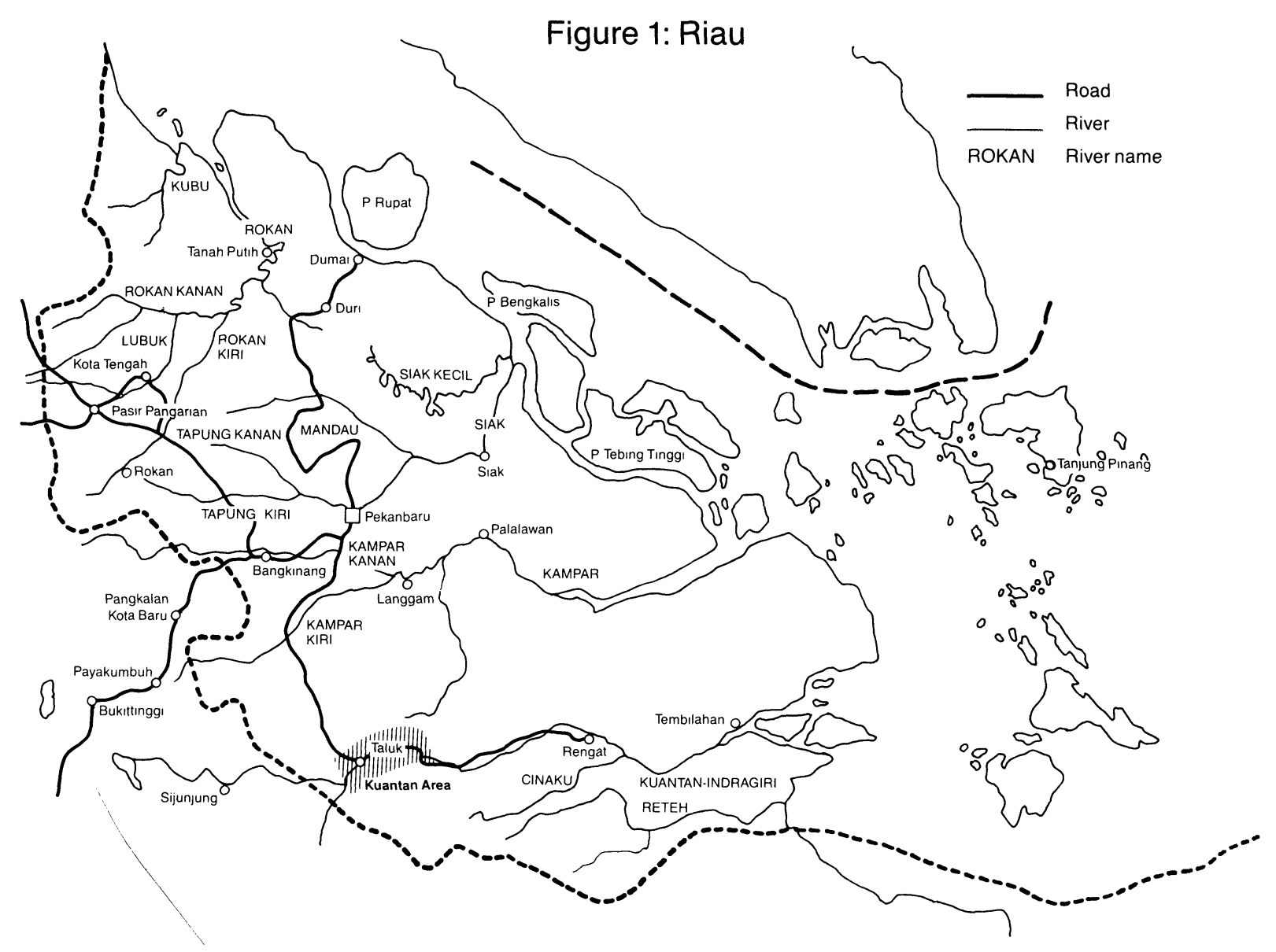

Figure 2: Schematic Representation of Settlement Patterns in Kuantan

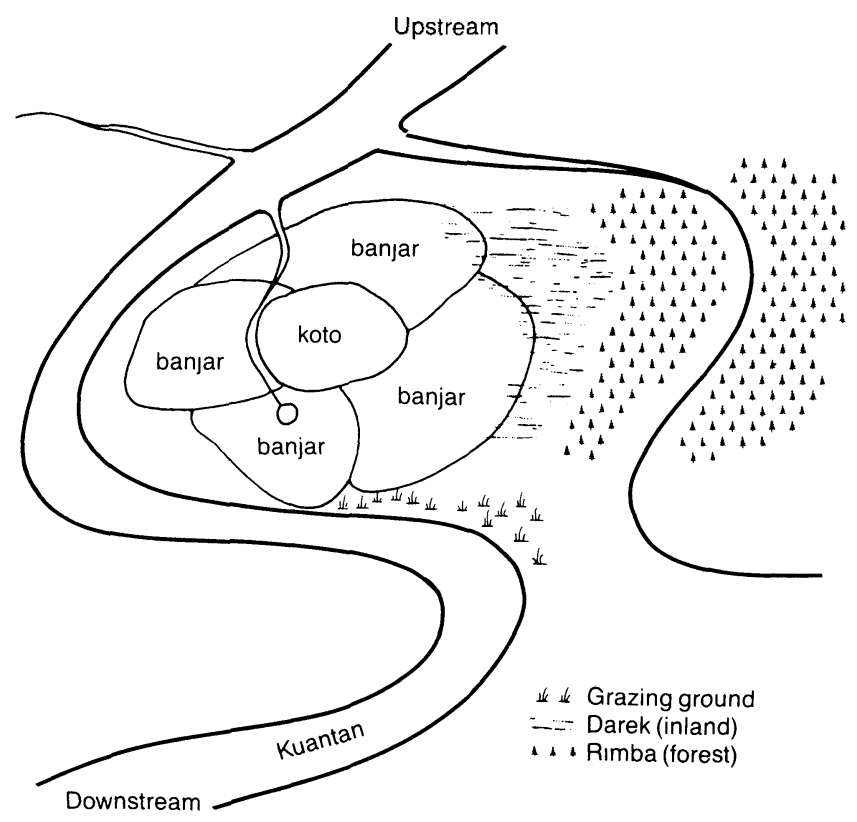


as a province in 1958. For instance, a Gubernatorial Resolution of 1966 stated that all the administrative villages in Riau were henceforth to be called kampung, with their heads as kepala kampung. However, these terms never became part of common parlance. ${ }^{26}$

Efforts toward a greater administrative uniformity culminated in the regulation called pemekaran desa (desa multiplication), which was issued in 1976,27 probably a response to the national "Law No. 5 of 1974 on Principles of Local Administration." As already mentioned, this law did not supply concrete provisions concerning the form and functioning of the lowest unit in the local administrative hierarchy. Nevertheless, it seems to have prompted some provincial governments to take actions toward restructuring village administration under their jurisdiction. Thus, for example, the governor of West Sumatra issued a Gubernatorial Resolution No. 155 of 1974 (No.155/GSB/1974), whereby a new structure of local village administration was proposed. Likewise, villages in North Sumatra, just as in Riau, seem to have been already subdivided before the introduction of the Village Law. ${ }^{28}$

Preparations for the desa multiplication in Riau had already been under way since 1974 and 1975. For instance, the camat (subdistrict head) of Tembilahan in the kabupaten of Indragiri Hilir submitted a proposal on how to carry out the multiplication in his subdistrict in an official letter to the bupati dated April 8, 1975. ${ }^{29}$ There are some indications that the regulation, as is the case with the Village Law of 1979, could not be simultaneously effected across the board in the province. One unpublished document, prepared for a "village [development] contest" (lomba desa) for the years 1979/80/81, mentions that the village slated for the contest from the subdistrict of Kampar was yet to be "multiplied" as of 1980.30 The village of Koto Dalam in Kuantan, where I stayed for several weeks between 1984 and 1985, was multiplied only in 1978.

\section{Negeri or Adat-cum-Administrative Village in Kuantan}

In order better to appreciate impacts of the desa multiplication regulation in Koto Dalam, let me briefly describe adat and society in Kuantan before the introduction of the regulation. One of the most salient features of Kuantan's adat and society is their remarkable uniformity. The "village" according to Kuantan adat is called "negeri" and there are but few variations between the negeri in terms of settlement patterns and adat social structure. ${ }^{31}$ People in many regions of central Sumatra follow the Minangkabau matrilineal adat, for example in areas along the upper Rokan, the Tapung, the Kampar, the Singingi, and along the upper Batang Hari (for some of these rivers, see Figure 1).

\footnotetext{
26 Monografi Daerah Riau (Jakarta: Proyek Pengembangan Media Kebudayaan, Ditjen. Kebudayaan Departemen Pendidikan dan Kebudayaan, c. 1975), p. 75.

27"Pola Pemukiman Daerah Riau" (Jakarta: Proyek Inventarisasi dan Dokumentasi Kebudayaan Daerah, Pusat Penelitian Sejarah dan Budaya Departemen Pendidikan dan Kebudayaan, 1980/81) (mimeographed manuscript), p. 2.

${ }^{28}$ Imran Manan, "Traditional Elite," pp. 82-83, 234; "Demokrasi, Tapi Berbau Feodal, " p. 23. For a brief review of the history of local administration in West Sumatra, sce Imran Manan, "Traditional Elite," pp. 222$23,230-35$.

${ }^{29}$ Masran Asmawi, "Masalah Pemekaran Kenegerian (Desa) Tembilahan Wilayah Kecamatan Tambilahan" (BA thesis, Akademi Pemerintahan Negeri, Pckanbaru, 1974/75), p. 60

30 "Keadaan Kegiatan dan Pembangunan Desa Kampar Kecamatan Kampar dalam Rangka Lomba Desa Tahun 1979/80/81" (typed report, 1980), p. 1.

${ }^{31}$ Information in this section basically comes from my research in Kuantan.
} 
Nowhere, either within or outside West Sumatra, can such a high degree of uniformity be found in applying Minangkabau adat as in Kuantan. What follows in my description applies to almost all the negeri in Kuantan with a few minor exceptions.

The physical layout of the negeri in Kuantan is highly uniform; one might say that there must have been commonly accepted "village-planning" there. The layout is schematically represented in Figure 2. The degree of uniformity is no doubt influenced by the ecological reality that practically all the negeri in Kuantan are located along the Kuantan-Indragiri river.

As is represented in Figure 2, the negeri consists of a koto, a sort of village capital, and several surrounding banjar or settlements. The koto is a settlement almost exclusively of houses, but it also accommodates the two most important institutions in the negeri: the adat council hall (balai adat) and the mosque (mesjid), which often stand next to each other. The koto is clearly the center of adat and religion.

The koto is also a center of ceremonial and ritual. As will shortly be explained more fully, there are four $s u k u$ or matrilineal clans in the negeri, each headed by its own adat leaders. Each matrilineal group has its rumah godang (large house) in the koto, which is large not necessarily in size but in distinction. It functions, or rather, used to function, as the symbolic center and focus of solidarity for the matrilineal group. For example, the rumah godang had a central role in ceremonies related to the rites of passage of its members, such as weddings. In fact, ceremonies involving the slaughtering of fourlegged, thus expensive, animals, according to some elders, had to be carried out in the koto up until about the 1930s. At least until the end of the colonial period, then, the koto was the center of the negeri in every respect. And it is perhaps because of this supremacy that the term "koto" is more frequently mentioned than "negeri" when the people of Kuantan discuss adat.

In contrast to the koto, which relates to the "extraordinary," the banjar are concerned with the "ordinary," that is, the day-to-day lives of the negeri populace. They are settlements encompassing both houses and agricultural lands, where a majority of the negeri population live, work, and spend their daily lives. ${ }^{32}$

Compared to the settlement patterns, socio-economic and political aspects of negeri life witnessed considerable transformations after Dutch control reached Kuantan in 1905. Nevertheless, the formal adat social structure has remained relatively resilient. As mentioned above, there are almost invariably four suku in the negeri of Kuantan. Each member of the negeri belongs to a suku whose membership is inherited matrilineally. The suku has four adat leaders. These are a penghulu (clan head), a monti (a kind of penghulu's executive officer) a dubalang (implementor of the penghulu's or monti's decisions), and a pegawai (Islamic functionary). The penghulu is the chief of the suku and, collectively, the four penghulu used to constitute the highest authority in the negeri before the arrival of the Dutch.

Marriage patterns, descent reckoning, and inheritance are regulated by adat. A man moves into the house of his wife's parents after the marriage, but he and his wife are expected to move out after a few years, and establish their own household nearby, particularly if the wife has younger sisters. This process is repeated every time a younger sister marries. Eventually the youngest sister, her husband, and children remain behind.

\footnotetext{
${ }^{32}$ In reality there have been some changes in this koto-banjar distinction. Since around the 1930s the koto has become more populated than its surrounding banjar in Koto Dalam.
} 
She inherits the house and looks after the elderly parents. In principle, people of the same suku may not marry each other. There is no regulation against negeri exogamy, that is, against marrying a person of another negeri, but in practice marriage partners are usually found within the negeri. Thus, the inhabitants of a negeri live in a very homogeneous community.

Adat regulations on lands are not so rigid. Except for some ricelands, most lands, especially rubber gardens, are transferrable. Far more important in one sense than lands, which were after all abundant in Kuantan, used to be heirlooms such as adat titles, weapons (e.g., keris, lances, and later cannons), banners (panji), and adat costumes. They, probably all foreign-made, bestowed status and magical power on their holders. The heirlooms, though of much diminished value nowadays, are the communal properties of a particular family line within a suku and are inherited matrilineally.

To summarize, the negeri or village in Kuantan is not simply a random collection of settlements. It has a characteristic geographical layout of the component settlements. The functions of the koto (the negeri capital) and the banjar (the other settlements), are distinctly specified as well as differentiated. The people of the negeri have properly assigned places in society. The negeri adat leadership is clearly defined and stratified. Interpersonal relations are demarcated and regulated in meaningful fashions. All of these observations hinge on the premise that the negeri is conceived of as a relatively autonomous adat community.

The above is an admittedly somewhat idealized picture of the Kuantan negeri. Although the Dutch introduced new elements into the internal workings of negeri politics, they never tried to disturb this framework, so that the Kuantan negeri basically survived Dutch colonial rule.

The consolidation of Dutch power and later the economic prosperity of the rubber boom in the early twentieth century did usher thitherto unfamiliar institutions into the negeri, such as the office of penghulu kepala (head penghulu) as negeri head, secular schools, modern Islamic schools, a well-coordinated system of rotating weekly markets, and village lapau (coffee shop-cum-sundry shops). According to adat, these institutions should probably be located in the koto, the negeri capital, but in reality they may not be. Access to road transportation and especially land access to the Dutch local offices often became a decisive factor in determining the locations of the new institutions. Inevitably the subsequent development of various settlements in the negeri was thereby greatly affected. The distinctive differentiation between the koto and banjar frequently collapsed if the new institutions were placed in a banjar instead of the koto. In the political arena the authority of penghulu steadily declined through the Dutch period, Japanese occupation, and post-independence period. Despite these changes, the basic framework of the nagari as the lowest administrative unit remained practically unaltered. No matter how negeri politics were conducted, and no matter what administrative policies were pursued by the higher authority, the position of the negeri as the adat-cum-administrative village was never challenged, either from within or, though perhaps grudgingly, from without. But in Kuantan it did change after the implementation of the desa multiplication 


\section{Desa Multiplication and Its Consequences}

Like the Village Law of 1979, the 1976 desa multiplication regulation of Riau necessitated the reorganization of existing villages in order to create desa. Under it the existing villages might be maintained in their current form, combined, or subdivided for this purpose. In so doing, proper attention was to be paid to such factors as population size, territorial size, and adat unity. In reality, the creation of desa under either the desa multiplication regulation or the Village Law of 1979, often meant breaking up existing villages. The central government, since the time of the first five-year plan (1969/701973/74), has allocated a fixed amount of annual bandes or bantuan desa (desa development subsidies) to every administrative village in the country through the provincial governments. The simple calculation is, the more administrative villages, the more subsidies for the province. In fact, the increased allocation of these subsidies was frequently mentioned to me by some local government officials in Riau as a positive feature of the desa multiplication and, thus, as an official justification for the regulation. It is as if the bandes were construed as a sweet coating over a bitter pill which had to be swallowed by villagers in cases of unpopular village fragmentation. ${ }^{33}$

The increased allocation of development subsidies works as a strong incentive for the provincial government to multiply the number of desa. In $1969 \mathrm{Rp}$. 100,000 was allocated per administrative village a year. This rose to Rp. 750,000 in 1980 and then Rp. $1,000,000$ in the following year. Currently the desa receives Rp. 1,350,000 a year for its, presumably self-initiated but often "administratively guided," desa development projects. ${ }^{34}$ Although the subsidies do not become revenues of the provincial government, they do help the desa to upgrade infrastructure, e.g., roads, bridges, and market facilities, at the grass-roots, and thus allow the provincial government to divert financial resources to larger development projects. The extra hundreds, and sometimes even extra thousands, of newly created desa then would provide substantial funds for the provincial government. 35

\footnotetext{
${ }^{33} \mathrm{My}$ view here may be a little too cynical. While doing research in West Sumatra in the early $1970 \mathrm{~s}$, I sometimes heard of considerable animosity between different jorong of a nagari concerning in which jorong the bandes was going to be used for a particular year. It is possible, though rather improbable since no local government official told me so in my research in Riau, that the generous distribution of bandes was partly to eliminate such animosity-a reasonable justification for the Village Law which any government official surely would have been eager to point out if it had been the case. The bandes is also known as Inpres desa or desa development subsidies by a presidential instruction.

34 "Proyek Inpres, Siapa yang Punya," Tempo, January 12, 1981, p. 37; "Each Village to get Rp.1 m. Amirmachmud," The Indonesia Times, February 14, 1981, p. 1; "Pemerintahan Desa," p. 27.

35The bandes are also "cost-efficient" from the government viewpoint. The bandes, in their implementation, are expected to be supplemented by swadaya masyarakat (society's self-help), that is, villagers' (supposedly) voluntary contributions of mainly labor and sometimes construction materials for the maximum utilization of bandes. These contributions, if calculated in monetary terms, could be substantial. For instance, Rp. $425,855,000$ of bandes was supplemented by swadaya masyarakat estimated to be worth Rp. 300,860,895 in Riau in 1979. For a comparison, the figures for 1983 were Rp. 1,371,500,000 and Rp. 598,085,000 respectively. See Riau dalam Angka 1979 (Pekanbaru: Badan Perencanaan Pembangunan Dacrah dan Kantor Sensus dan Statistik Propinsi Daerah Tingkat I Riau, 1982), p. 494 and Riau dalam Angka 1983 (Pekanbaru: BAPPEDA dan Kantor Statistik Propinsi Riau, 1983), p. 516. The question of "cost-efficiency" was brough afresh to my mind when I was doing research in rural Malaysia in 1988. Village-level rural development projects in Malaysia are funded on the "request" system in contrast to what one may call the "flat sum" system in Indonesia. Every year administrative villages in Malaysia send requests for specific project funds to the local and/or central governments. As is usually the case with scrambling for fund allocations, requests have to be inflated in anticipation of cuts; yet swadaya masyarakat would more or less result in deflating the amount of funds to be
} 
Table 3: Village Reorganization in Riau

\begin{tabular}{lrcrc} 
"Districts" & \multicolumn{2}{c}{1961} & \multicolumn{2}{c}{1981} \\
& $\begin{array}{c}\text { Number of } \\
\text { Desa }\end{array}$ & $\begin{array}{c}\text { Average Population } \\
\text { per Desa }\end{array}$ & $\begin{array}{c}\text { Number of } \\
\text { Desa }\end{array}$ & $\begin{array}{c}\text { Average Population } \\
\text { per Desa }\end{array}$ \\
Pekanbaru & 2 & 34,574 & 33 & 5,738 \\
Bengkalis & 216 & 1,378 & 278 & 1,894 \\
Dumai & NAP & NAP & 12 & 5,573 \\
Kepulauan Riau & 148 & 1,862 & 168 & 2,563 \\
Indragiri Hula & 85 & 2,104 & 292 & 840 \\
Indragiri Hilir & 81 & 2,566 & 108 & 3,783 \\
Kampar Hulu & 59 & 2,962 & 151 & 2,243 \\
Kampar Hilir & 46 & 734 & 60 & 923 \\
Riau & 637 & 1,943 & 1,102 & 2,052
\end{tabular}

Sources: Sensus Penduduk 1961: Penduduk Desa Sumatra, pp. 182-193a; Penduduk Propinsi Riau: Hasil Registrasi Penduduk Akhir 1981 (Pekanbaru: Kantor Statistik Propinsi Riau, 1982), pp. 1, 5.

The desa multiplication regulation brought about the mushrooming of desa in Riau. Between 1961 and 1981 the number of administrative villages increased by 73 percent. Table 3 shows that this increase, which can not be wholly attributed to demographic factors, is not evenly distributed among the provinces' districts. ${ }^{36}$ Other than Pekanbaru, the provincial capital of Riau, which has experienced rapid urbanization for the last twenty years or so, the multiplication of desa was most pronounced in the western region of inland Riau. In these areas the ethnic composition of the local population is relatively homogeneous and adat is still supposed to maintain a strong hold over villagers' lives. In contrast, Islam or syarak (Islamic laws) are said to be more important than adat in regulating people's lives along the coastal region and in island Riau. If we take the example of Kuantan, the number of administrative villages increased by more than 500 percent from 1961 to 1981, with the 30 negeri in Kuantan, encompassing the subdistricts of Kuantan Mudik, Kuantan Tengah, Kuantan Hilir, and Cerenti, becoming 164 desa as of 1981.

Let us take the case of the former Negeri Koto Dalam to show how a negeri was subdivided into several desa. Koto Dalam is a relatively new negeri in Kuantan, probably

requested. Thus disincentives of swadaya masyarakat are built into the Malaysian funding system of development projects. It is no wonder that swadaya masyarakat are practically non-existent despite the Malaysian government's efforts to the contrary.

The bandes are by no means "cost-effective" from the villagers' viewpoint. Villagers in general have little say in determining what kind of development project should be financed by the bandes. Consequently they sometimes end up contributing labor to a project they do not really nced. A case in point were the wells dug in Koto Dalam A few years before I visited Koto Dalam for research, some of its desa used bandes for digging their own wells and cementing the surrounding areas. The wells were supposed to ease the lives of desa people who had to go to rivers to fetch water. It turned out that the wells were seldom used, for people go to rivers not simply to fetch water but to bathe, do laundry, and relicve themselves at the same time.

36 Table 3 makes a distinction between Kampar Hulu and Kampar Hilir to highlight a contrast between inland Riau and the coastal area. There are, in reality, no such administrative units. Four of the fifteen kecamatan in Kabupaten Kampar are classified into Kampar Hilir: Kuala Kampar, Bunut, Pangkalan Kuras, and Langgam. Dumai is a relatively new kota administrasi (administrative city) which was incorporated in Bengkalis in 1961. A kota administrasi is an urban administrative unity which is not yet large enough to be a kotamadya (municipality). 
being settled in the early nineteenth century. There were originally four settlements in Koto Dalam: Banjar Tua, Sungai Banyak Ikan, Koto, and Pasir Batu Mandi. Another banjar, Tanjung Labuh, was later created because of population expansion into the darek (inland areas away from the Kuantan-Indragiri), resulting in a total of five settlements, i.e., one koto and four banjar, at the time of the desa multiplication in Koto Dalam in 1978. Other than these five settlements, all of which became separate desa in 1978, two more desa, Kasang Tinggi and Teratak Baru, emerged out of some areas of the banjar plus darek. ${ }^{37}$ Koto Dalam then finally became seven desa. Their names, populations, and territorial sizes are shown in Table 4. Considering the small population sizes of some of the desa, we can see that this degree of multiplication was carried out with the principal aim of increasing the number of desa.

Table 4: Basic Information on Koto Dalam (1980)

$\begin{array}{lcc}\text { Desa } & \text { Population } & \text { Territory (in } \mathbf{k m}^{2} \text { ) } \\ \text { Koto } & 820 & 8.28 \\ \text { Banjar Tua } & 683 & 10.97 \\ \text { Sungai Banyak Ikan } & 317 & 9.67 \\ \text { Pasir Batu Mandi } & 428 & 9.77 \\ \text { Tanjung Labuh } & 128 & 10.17 \\ \text { Kasang Tinggi } & 55 & 8.80 \\ \text { Teratak Baru } & 81 & 7.88 \\ \text { Total } & 2,512 & 65.54\end{array}$

Administratively, the seven desa are completely autonomous. Each has its own desa head or kepala desa, who, according to regulations, should have a few assistants. Each also has a separate office building (kantor kepala desa) although the desa head seldom works there. He and his assistants receive monthly honoraria for their positions, but these do not provide a living wage. Worse, these monthly honoraria are paid only every three months, often not even on schedule. Thus, the desa head and his assistants have to pursue their livelihoods elsewhere. There is no official coordinating body to mediate the relations among desa heads who previously were the members of Negeri Koto Dalam. The head of Desa Koto, despite his settlement's special position as a capital of former Negeri Koto Dalam, has no exalted position vis-à-vis heads of the surrounding desa. The desa heads are equal in their positions. They report directly to the camat in the nearby small market town.

The desa are now neatly formalized in administrative terms. They are structured so as to be highly responsive to directives from above. Unfortunately, they are less responsive to needs from below, for the desa hardly corresponds to the world the rural populace of Kuantan inhabits. People still live and work within the circumference of the former negeri, not of the desa. Let us again take the example of Koto Dalam on this point.

People in the former Negeri Koto Dalam still mostly marry inside the negeri, often crossing the present desa boundaries. Thus, it is common for a man's parents to live in a

${ }^{37}$ All the settlement names mentioned here are pscudonyms except Koto. 
different desa from that of his current domicile; for the man, after his marriage, moves to the desa of his wife. Partly because of this, it is also not unusual either for one's residence and one's agricultural land to be in different desa. In such a situation a person has little sense of desa-loyalty and is reluctant to contribute his labor to assist whatever development projects the desa head might propose.

Some public facilities are for the mutual benefit of several desa in Koto Dalam. An elementary school in former Koto is attended by children from a few surrounding desa. Practically every inhabitant of former Koto Dalam has to cross the Long Bridge (Jembatan Panjang) between Koto and Sungai Banyak Ikan, to go to his or her riceland or to rubber gardens. Yet Desa Koto is now having to shoulder single-handedly the maintenance of the school and the bridge.

A few small rivers flow through Koto Dalam. It is important to maintain good drainage so that ricelands along these rivers will not be unduly flooded during the rainy season. Yet no desa heads have been able to coordinate cooperative activities among people of different desa in order to clean the rivers. Inhabitants of each desa think it is not their responsibility.

Previously, the rice-planting season was communally regulated in Koto Dalam. Magicians ( $d u k u n)$ decided when to start preparing seed beds by consulting the movement of the Orion's Belt (Bintang Tiga) and an age-old calendrical system. People gathered in a field on an appointed day, prayed together, had a cow or water buffalo slaughtered, and performed appropriate rituals on some riceland. A feast was held afterward in the field. There the adat leaders announced the planting schedules and regulations to be observed during the period of rice cultivation. For example, cattle had to be tied or taken to the grazing-ground and chickens were to be penned. There were penalties for violations. The coordination of rice planting no longer takes place. Since 1981 people have been induced to plant new varieties of rice which mature much more quickly than the local varieties. As a result, they plant rice whenever they like, in the expectation of harvesting rice twice or three times a year. Unfortunately, there has also been a rampant increase in field rats and grasshoppers, which can now find food on riceland practically at any time of the year, so this expectation has not materialized. Some people in Koto Dalam have begun to wonder whether they should again coordinate their rice-planting calendar, but there is no way to build up anew an organized body which can coordinate inter-desa activities. ${ }^{38}$

Adat leadership itself has been considerably undermined in its own sphere of influence by the desa multiplication. Authority of adat leaders mainly applies at the negeri level. Yet the provincial government of Riau, which administers diverse adat communities, has not encouraged, let alone legislated, the formation of such a body as the KAN or Nagari Adat Council found in West Sumatra, in compensation for abolishing negeri in Kuantan. It is said that with the increasing political clout, though not necessarily authority, of desa heads, people now often bring their adat problems to the desa heads rather than to the tuo banjar or other adat leaders.

\footnotetext{
${ }^{38}$ When I revisited Koto Dalam briefly in mid-1988, I was told that the Koto Dalam people had managed to coordinate again their rice-planting calendar for the $1987 / 88$ agricultural season. It is noteworthy, however, that the initiative for this action did not come from pcople in Koto Dalam but from a well-respected, influential person of national stature who was born in Koto Dalam but now resides in Pekanbaru.
} 
Some desa in Koto Dalam are clearly too small in population size to be viable as administrative units. Some years ago the seven desa in Koto Dalam were encouraged by the camat to use that year's development subsidies for buying a small generator each. It soon became apparent that the two smallest desa could not even run the generators because their running costs were too great to be shared by such few people. ${ }^{39}$ Probably as a result of their small populations, too, none of the seven desa in Koto Dalam has dusun (sub-desa administrative units) or a Desa Deliberation Council (consultative body in desa administration) in good order, whose existence is stipulated by the Village Law of 1979.

Although the heads of the seven desa used to be members of the same negeri, cooperation among them is difficult. Having a vested interest in maintaining the newly found political and economic resources at their disposal, they are more interested in jealously guarding their small fiefdoms than in cooperation. It is out of the question, for example, for the seven desa heads to pool their annual bandes and to launch a large development project such as replacing the aged Long Bridge with a new one. One possible solution to avoid this kind of impasse would be to re-establish a negeri as the lowest administrative unit and yet give bandes to the present desa through the office of negeri head. Such an arrangement would allow flexibility in the usage of the subsidies. It would, however, probably not be an acceptable option to the central government because it would give too many financial resources to a negeri head.

All in all, then, desa multiplication has certainly increased the amount of development money available at the village level, but this has been secured by sacrificing a sense of community rooted in adat and history. The desa multiplication has torn apart the close relationship between adat and administration in Kuantan. Nowadays the desa in Koto Dalam increasingly seem to anchor their raison d'etre more to their position in the local administrative hierarchy than to adat relations with their "compatriot" banjar in former Negeri Koto Dalam.

Kuantan in general and Koto Dalam in particular may not be good examples for assessing the merits and, especially, demerits of the Village Law, because of their distinct adat which greatly affects, or used to affect, the social and political life of the people in this area. It is suggestive, however, that the desa heads of former Negeri Koto Dalam fail to cooperate among themselves despite their desa's strong interrelationship in adat, marriage patterns, and economic life. ${ }^{40}$

The desa heads are basically discrete cogs in the local administrative hierarchy in Indonesia. They are expected to know how to receive orders from the camat and in turn to deliver them to desa inhabitants. It is not part of structural requirements in local administration that the heads of even adjoining desa should know how to negotiate cooperation with each other, especially upon their own initiative. The whole local administrative structure in Indonesia resembles what some sociologists call a baseless

\footnotetext{
${ }^{39}$ With one exception, the other generators are also inoperative now because of mal-handling and malmaintenance and/or the lack of desa pcople's willingness to pay for running costs.

${ }^{40}$ In this respect adat leaders, by tradition, scem to be better equipped to negotiate and arbitrate among themselves. I had a chance, in Bukittinggi in 1988, to talk to a European project leader who worked for an irrigation project near Lake Singkarak in West Sumatra. The project covers several desa in this area. He told me that it was essential to have adat leaders, i.c., penghulu or matrilincage lcaders, from these desa on an advisory board of the project so that differing interests among the desa could be ironed out; evidently the desa heads alone cannot accomplish such a feat. In Koto Dalam too, adat leaders used to be able to coordinate the agricultural calendar among the banjar which adjoin each other but belong to different negeri.
} 
triangle. The chain of command, in our case from the central government to the province, district, subdistrict, and village, is clearly demarcated in the shape of an everexpanding equilateral triangle. It lacks, however, a base line, a structurally prescribed relationship between desa heads, to make it into a regular triangle. It is ironic that actual face-to-face encounters among heads of administrative villages are probably far more frequent now than ever. The desa heads of one kecamatan, according to my experience in Kuantan, are usually called to the kecamatan office once a week or once every two weeks for regular briefings. ${ }^{41}$ Yet they are there to receive orders, not to discuss on their own initiative inter-desa projects or problems. It is through the expansion and consolidation of a baseless triangle that the desa multiplication and the Village Law of 1979 have more or less accomplished a remarkable uniformity in the village administration of Indonesia.

\section{Political Dimension of the Village Law}

According to a stipulation in the Regulation No. 4 of 1981 of the Minister of Internal Affairs, the desa should have a minimum population of 2,500 or minimum number of households of 500.42 Many desa in the province of Riau barely meet this stipulation, judging from low average population sizes per desa in some of the districts (Table 3 ). This irregularity is not solely limited to Riau; it is also found, for example, in Aceh and Bengkulu (Table 2).

As already mentioned, one powerful incentive for multiplying the numbers of desa, is the augmentation of village development subsidies. This explanation, however, only provides an economic motive for the provincial and not for the central government.

It is indeed surprising that the central government seems to have condoned massive violations of the Ministry of Internal Affairs' stipulation, for these extra desa inevitably impose an enormous financial burden on Jakarta. Extra desa offices have to be built, newly appointed desa heads and their staffs (theoretically four to six persons) have to be paid honoraria, and, of course, an added number of desa development subsidies have to be distributed. Nevertheless, there seems to have been no effort by the central government to enforce the size regulations. I may add here that such a costly administrative reorganization was only possible financially after Indonesia earned windfalls in oil revenues through the rise in world oil prices through the 1970 s.

From the viewpoint of the central government, fragmentation of pre-existing villages does present some obvious political advantages. By extricating administration from adat and by streamlining and standardizing the structure of village administration, the central government has considerably increased its control over the desa. For example, the desa multiplication, according to my observations in Kuantan, was often coupled with changes in desa-level leadership. Younger people, presumably more developmentminded but usually without any adat positions, managed, in many cases, to become desa heads. Owing their political ascendance to the provincial government's official

\footnotetext{
${ }^{41}$ Such an arrangement is made because a camat now has so many desa under his supervision; it is simply too time-consuming for him or even his deputy to visit cach desa. Improved transportation systems also make this kind of arrangement possible. When doing research in West Sumatra in the early 1970s, I had the impression that it was more common then for the kecamatan office to send letters of instruction than to call desa heads (then nagari heads in West Sumatra) to briefings.

${ }^{42}$ Kansil, Kitab Undang Undang, p. 339.
} 
endorsement, they are obviously far more responsive to directives from above than older adat leaders.

According to the Village Law of 1979, to which the provincial government of Riau now obviously subscribes, the desa head is elected for the eight-year term. ${ }^{43}$ The district and subdistrict officials keep close tabs on the election procedure of a desa head. The election committee (panitia pengawas), chaired by a camat, finalizes a list of candidates after a stringent screening process. ${ }^{44}$ Significantly, one condition of eligibility for a candidate is age; the minimum and maximum ages of eligibility are 25 and 60 respectively. The minimum educational requirement is junior high school, which also handicaps older candidates. ${ }^{45}$ A desa head, even securely in office for a few years, may be dismissed by a bupati if he is judged unfit for the job by the local government. It is not that these "administrative guidances" concerning the position of a desa head did not exist before. Yet the guidances used to be far less standardized compared to the Village Law. Under Part II of Chapter II of Law No. 19 of 1965, it is stated: "Regulations concerning the election, appointment and officiation, suspension and discharge of a desa head are to be drawn up by the Level I Local Government (province), with attention being paid to local customs." 46

Not only through political means but also through financial means the government can now wield greater control over desa heads than before. Some adat-cum-administrative villages used to have their own revenue sources. A good example are the marga in Jambi and South Sumatra, which used to secure revenues by auctioning off the rights to collect 10 percent rubber taxes (lelang pasar getah) in Jambi or commercial fishing rights (lebah lebung) in marga ponds and rivers in eastern South Sumatra. In accordance with adat, a pasirah, marga head, was entitled to 10 percent of the revenues. ${ }^{47}$ I do not know what happened to these revenues after the Village Law, but most probably, they became inoperative after the marga were replaced by desa. It is a political reality that the government is inclined to remove from the administrative village the revenue sources prescribed by adat, e.g., "taxation" on the commercial exploitation of forest products. ${ }^{48}$ The desa, especially outside Java, are now more or less completely dependent on government funds, above all desa development subsidies, for their revenues. ${ }^{49}$

43 The desa head is eligible for another eight-year term, with the total service limited to sixteen years. The reason for this one-reelection-only policy is explicitly stated in the State Gazette No.56 of 1979: "to avoid the possibility of [desa heads'] motivation to take charge of desa administrative leadership declining." See Watjiok Saleh, UU RI No.5 Tahun 1979, p. 31.

${ }^{44}$ Kansil, Kitab Undang Undang, pp. 352-54.

${ }^{45}$ Watjik Saleh, UU RI No. 5 Tahun 1979, p. 14 Under the Law No. 19 of 1965, the minimum educational requirement for village headmanship was elementary school, and age-wise the village head had to be at the youngest 25 years old, without any limit for maximum age. Sce Bayu Surianingrat, Pemerintahan Administrasi Desa, pp. 299-300.

46Ibid., p. 299.

47"Pemerintahan Desa," pp. 58-59; Tsuyoshi Kato, "Village Administration" in "Land Tenure and Village Administration," ed. E.E. Lipinsky and T. Kato (mimcographed report of Sumatra Regional Planning Study Province Jambi) (Jakarta: Ministry of Public Works and Powcr, c. 1974).

48"Pemerintahan Desa," pp. 59-62.

${ }^{49} \mathrm{~A}$ common additional source of revenue are fees collected for preparing various administrative forms for desa inhabitants. One basic contradiction in desa finance is that there are no formal routine budgets for desa offices, yet a relatively large amount of routine expenditures is regularly expected. One "routine" expenditure is to entertain tamu or guests who come from kecamatan or kabupaten offices, sometimes even from provincial offices for, for instance, inspection. Some decorations are put up in the desa, entertainments 
The desa heads and their staff are expected to become members, or at least active supporters, of Golkar (Functional Groups), the government party. As early as 1972 and 1973, when I was doing research in West Sumatra, I encountered a few cases where wali nagari (nagari heads or village heads) were dismissed as a result of their refusal to switch their allegiance from Parmusi, an Islamic party, to Golkar. In my research in Kuantan itself, I observed copies of Suara Karya (The Voice of Functional Groups), a Golkar newspaper, being regularly distributed through the camat's offices to desa heads and their staff. The multiplication of desa basically means an expansion of Golkar activists at the grass-roots' level, who, as already mentioned, owe their political ascendance to the government's endorsement and thus are motivated to cater to its wishes. They can be turned into a strong political asset for the central government, particularly during election periods. Political pressure was reportedly applied to village heads and rural officials, for example, in the 1977 and 1987 general elections. ${ }^{50}$

Admiral Sudomo, head of the Command for the Restoration of Security and Order (Kopkamtib), and General Amir Machmud, the minister of internal affairs, both in the Third Development Cabinet (1978/79-1983/84), once suggested that all desa heads be made into civil servants. Their intention was to change the position of desa head from an elective one to an appointive one, theoretically even with the possibility of transferance, thereby increasing the government's control over them, at the time of general elections or otherwise. ${ }^{51}$ So far this suggestion has not been put into practice, due to the tremendous financial outlays that would be involved in such an undertaking. Yet the idea has not been altogether barren, at least for kelurahan or administrative villages in the capitals of subdistricts, districts, and provinces, together with those in Jakarta. Government regulation No. 55 of 1980, issued on December 31, 1980, decreed that all kelurahan heads (lurah) be appointed as civil servants. ${ }^{52}$ Accordingly, the kelurahan heads in the country-4,849 of them according to an official tally of the Ministry of Internal Affairs as of February 14,1981-have been step by step made into civil servants since the beginning of January 1981. For instance on March 9, 1981 in Padang, Amir Machmud officiated at the appointment of 406 lurah in West Sumatra, together with their staff of 2,436 (406 multiplied by six), as civil servants. ${ }^{53}$ The political and administrative ingenuity of the government regulation is that it ascertains the political allegiance of lurah both ways; lurah are now made into civil servants and, at the same time, civil servants are now allowed to become lurah. ${ }^{54}$

prepared, and dinners served for important guests. The desa head has to finance these expenditures by his own wit. The commonest way of doing this is to "appropriate"part of bandes. There is but a thin line between appropriations and embezzlements. According to some camat in Kuantan, most popular complaints, conveyed by desa people to the kecamatan offices, concern the desa heads' embezzlements of bandes and/or other funds for desa development projects. Perhaps not surprisingly, the camat are more understanding of the desa heads' predicament than critical of their possible excesses. A Desa Deliberation Council, even if formed at all, seldom holds a mecting, partly because the desa head, the chairman of the council, is reluctant to finance it, in terms of providing tea and swcetmeats, "by his wit."

50 "Second Parliamentary Election," Asian Survey 18, 2 (1978): 179; R. William Liddle, "Indonesia in 1987: The New Order at the Height of Its Power" ibid., 28, 2 (1988): 181.

51 "Cutting headmen down to size," Far Eastern Economic Review, November 9, 1979, p. 28.

52 "Better administration needed in increased rural development activities," The Indonesia Times, February 21, 1981, p. 1.

53 "Di Sum-Bar Ada Lurah," Tempo, March 28, 1981, p. 59.

${ }^{54}$ Kansil, Kitab Undang Undang, pp. 423-27 . 
It is noteworthy that the provinces where the number of desa increased dramatically after the Village Law of 1979 , especially West Java, South Kalimantan, and provinces in Sumatra, tend to be the ones where Golkar had lost votes between the 1971 and 1977 general elections (compare Tables 1 and 5).55 The association between the general election results and the Village Law of 1979 may not be totally fortuitous. An article on the Village Law in" the Far Eastern Economic Review was aptly titled "Cutting headmen down to size: A new system for watching over village rulers could have far-reaching results in 1982's national elections." According to the interpretation of this article, "the government may have found a way to have its village government cake and eat it" through the Village Law, that is, the government would be able to tighten its hold over the desa heads, without necessarily appointing desa heads as civil servants. ${ }^{56}$ It is interesting, in this vein, to observe that the lurah were made into civil servants one year before the 1982 general elections, after Golkar had apparently been less successful in winning votes in urban areas than in rural areas in the 1971 and 1977 elections. ${ }^{57}$

So far the Village Law of 1979 has proved politically positive for the central government. However, there is one potential trouble spot in the future, even from its viewpoint. A very peculiar feature of administrative reorganization under the Village Law is that, despite the phenomenal multiplication of desa, the number of kecamatan (subdistrict) has so far increased but little (Table 6). The kecamatan increased by only 11.7 percent between 1974 and 1986, while the number of administrative villages increased by 35.5 percent. The most glaring examples are in Sumatra. In 1956, in Sumatra a kecamatan office had, on the average, nine administrative villages under its jurisdiction and, in 1975, fourteen. In 1986 it had thirty desa under it. Its administrative burden is all the heavier now, because the increasing tendency toward centralization and bureaucratization of Indonesian society under the Suharto regime must have added extra jobs to the roster of the kecamatan's administrative duties.

It is true enough that the educational backgrounds of camat have been upgraded, together with the kecamatan office facilities. When I conducted research in West Sumatra in the early 1970s, only a few camat in the province had BA degrees in public administration. They worked in aged offices and their official transportation means was a motor cycle. The situation now is considerably different, with offices rebuilt and camat, now generally MA holders in public administration, supplied with official cars driven by chauffeurs. Nevertheless, the disproportionate increase in the number of administrative villages per kecamatan must have created strains on the functioning of the local administration. For example, very few, if any, desa in Kuantan have a properly functioning Desa Deliberation Council, for the camat offices are not well enough staffed to supervise the formation and functioning of such an organization in all the desa under their supervision.

\footnotetext{
${ }^{55}$ The figures in Table 5 may not tally in details with those found in some other sources. However, the general trends, I believe, are the same.

56"Cutting headmen down to size," pp. 28-29.

${ }^{57}$ At the national level this trend is clearly shown in Jakarta (Table 5). For the provincial level I only have data for Riau. Golkar gained merely 48.8 percent and 42.0 percent of the votes cast, respectively in the 1971 and 1977 elections for the national representatives; the figures for the entire province were 75.2 percent in 1971 and 63.3 percent in 1977. See Riau dalam Angka 1978 (Pekanbaru: Badan Perencanaan Pembangunan Daerah dan Kantor Sensus dan Statistik Propinsi Dacrah Tingkat I Riau, 1980), p. 83. There are no basic differences between figures for the elections of national representatives and those of provincial or district representatives. See ibid., pp. 84-85.
} 
Table 5: Percentage of Votes Won by Golkar in Past General Elections for Each Indonesian Province

Provinces

Aceh
North Sumatra
West Sumatra
Riau
Jambi
South Sumatra
Bengkulu
Lampung
West Java
Jakarta
Central Java
Yogyakarta
East Java
West Kalimantan
Central Kalimantan
South Kalimantan
East Kalimantan
North Sulawesi
Central Sulawesi
Southeast Sulawesi
South Sulawesi
Bali
West Nusa Tenggara
East Nusa Tenggara
Maluku
Irian Jaya
East Timor
Indonesia

\% Won by Golkar

$\begin{array}{rrrr}1971 & 1977 & 1982 & 1987 \\ 63.3 & 41.2 & 37.0 & 52.0 \\ 70.1 & 66.5 & 72.5 & 72.8 \\ 63.2 & 69.1 & 60.4 & 78.6 \\ 77.0 & 63.3 & 71.7 & 79.7 \\ 88.2 & 83.5 & 84.8 & 88.9 \\ 62.6 & 49.8 & 56.0 & 69.3 \\ 82.7 & 76.4 & 70.6 & 84.8 \\ 72.4 & 61.8 & 59.4 & 87.0 \\ 76.1 & 66.3 & 63.3 & 71.3 \\ 46.7 & 39.3 & 45.0 & 50.2 \\ 50.3 & 52.6 & 60.5 & 68.2 \\ 63.4 & 56.6 & 60.6 & 70.2 \\ 53.6 & 58.8 & 56.8 & 71.2 \\ 66.7 & 68.9 & 71.0 & 68.7 \\ 79.0 & 69.9 & 84.2 & 89.2 \\ 64.8 & 49.7 & 59.3 & 71.8 \\ 54.8 & 57.0 & 61.3 & 67.8 \\ 60.7 & 72.9 & 87.1 & 87.5 \\ 76.8 & 79.3 & 81.2 & 83.1 \\ 92.3 & 96.1 & 96.9 & 97.1 \\ 78.4 & 85.2 & 89.2 & 90.0 \\ 82.8 & 85.4 & 88.3 & 88.1 \\ 69.8 & 57.5 & 68.6 & 82.6 \\ 67.4 & 90.3 & 96.4 & 94.7 \\ 46.8 & 71.9 & 75.2 & 81.5 \\ \text { NAP } & 86.9 & 92.5 & 93.0 \\ \text { NAP } & N A P & 99.5 & 93.7 \\ 62.9 & 62.1 & 64.3 & 73.2\end{array}$

Sources: Ajia Doukou Nenpou 1978 [Asian Affairs 1978] (Tokyo: Ajia Keizai Kenkyuujo, 1978), p. 469; Tounan Ajia Youran 1983 [Southeast Asian Handbook 1983] (Tokyo: Tounan Ajia Chousakai, 1983), pp. 7/29-7/30; Tounan Ajia Youran 1988 [Southeast Asian Handbook 1988] (Tokyo: Tounan Ajia Chousakai, 1988), pp. 7/30$7 / 31$. 
Table 6: Historical Change in Number of Kecamatan in Indonesian Provinces

Provinces

Aceh
North Sumatra
West Sumatra
Riau
Jambi
South Sumatra
Bengkulu
Lampung
West Java
Jakarta
Central Java
Yogyakarta
East Java
West Kalimantan
Central Kalimantan
South Kalimantan
East Kalimantan
North Sulawesi
Central Sulawesi
Southeast Sulawesi
South Sulawesi
Bali
West Nusa Tenggara
East Nusa Tenggara
Maluku
Irian Jaya
East Timor
Indonesia

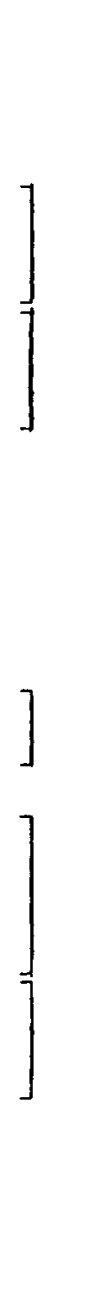

\section{6}

105

170

158

128

353

20

488

72

513

70

79

35

160

128

34

NAV

NAP

2,513
Number of Kecamatan

$1961 \quad 1973$

1986

$130 \quad 136$

$177 \quad 202$

$85 \quad 100$

$67 \quad 76$

$36 \quad 40$

$84 \quad 94$

$23 \quad 24$

$61 \quad 76$

$385 \quad 439$

$27 \quad 30$

$492 \quad 498$

$74 \quad 73$

$544 \quad 578$

$108 \quad 108$

$80 \quad 82$

$87 \quad 100$

$70 \quad 72$

$81 \quad 83$

$61 \quad 62$

$43 \quad 45$

$167 \quad 170$

$50 \quad 51$

$56 \quad 59$

$99 \quad 108$

$51 \quad 56$

$33 \quad 117$

NAP 63

Sources: For 1956, 1961, and 1986, the same sources as in Table 1; Statistik Indonesia 1974/1975 (Jakarta: Biro Pusat Statistik, 1976), p. 18. 
A case in point, epitomizing the above problem, is the district of South Tapanuli in the province of North Sumatra. As of 1981 there were 1,568 desa for the total of seventeen kecamatan in the district: an astounding average of ninety-two desa per kecama$\tan .{ }^{58}$ While conducting research in Kuantan, I observed that there were usually a dozen or so permanent staff members in kecamatan offices. If this is the case in South Tapanuli, one wonders how the kecamatan offices there are coping with overflowing administrative chores. It is no surprise that the district office of South Tapanuli, against general trends in North Sumatra, actually proposed in 1978 combining the existing desa into 241 administrative villages, in order, among other things, to better supervise the villages. 59 There is no indication that the proposal has been approved by the Ministry of Internal Affairs.

Whether we agree with it or not, the central government is apparently determined to pursue the standardization of the administrative village and its functioning in Indonesia, and to strengthen government control over local administration. Under the New Order of President Suharto, the nature of local administrative work itself has been greatly standardized down to the village level. For example, the family registration, application for KTP (Kartu Tanda Penduduk or identification card), and issuance of travel documents are now all processed more or less according to the same administrative procedures in any desa of any province in Indonesia. Considering administrative requirements of a complex modern state, it is inevitable that the central government generally becomes intent on standardizing and centralizing the local administrative structure. As far as the Village Law of 1979 is concerned, however, initial experience in Kuantan so far indicates that such a policy of standardization and centralization cannot be carried out without heavy cost, particularly at the grass-roots.

The Ministry of Internal Affairs is not unaware of some of the problems incurred by the Village Law mentioned in this article. It commissioned research on desa administration in Irian Jaya in March of 1986 and later in ten other provinces in January of 1988. The research report points out problems associated with "deadatisasi" or de-adat-ization of village administration, some extreme cases of desa fragmentation, lack of recognized authority on the part of some of the new desa heads, and frequent failures to staff properly the desa administrative apparatus such as the Desa Deliberation Council and dusun heads. The report's general conclusion is that the actual implementation of the Village Law is, up to now, far from its professed objective, to wit: "the state of affairs concerning Desa administration is to be made uniform as much as possible, with due respect for various local conditions of Desa and stipulations of adat istiadat still in existence, in order to strengthen Desa Administration so that [we will be] more competent to mobilize society in its participation in development and to run Desa administration increasingly more extensively and efficiently." 60

As yet it is uncertain whether this report will eventually bring the Ministry of Internal Affairs to reconsider the Village Law of 1979. This is all the more so because many ministers, including the minister of internal affairs responsible for commissioning the above report, were replaced in the Fifth Development Cabinet whose composition was announced in March of 1988. In the meantime, the rural populace in Indonesia has to

\footnotetext{
58 Daftar Nama dan Kode Desa/Kelurahan se Indonesia (Jakarta: Alda, 1983), pp. 12/10-12/33.

59 "Demokratis, tapi Berbau Feodal," p. 23. As previously mentioned, villages in North Sumatra seem to have been already subdivided before the introduction of the Village Law.

60 "Pemerintahan Desa," passim; "Debt drain on devclopment," p. 27.
} 
wait on the side lines, without being asked if the standardization and centralization of local administration under the Village Law have been worth their sacrifices.

The ultimate irony of the Village Law of 1979 is that it clearly violates the spirit of the 1945 Constitution of Indonesia, the very constitution President Suharto has been capitalizing on in legitimizing his New Order. Article 18 of the 1945 Constitution concerns local administration. It states:

The division of the Indonesian territory into large and small areas with their administrative structures is to be determined by law, by considering and noting the basis of consultation in the system of state administration and the original rights of the areas which have special attributes.

The article is further elaborated in the "Explications of the Indonesian State Constitutions" (Penjelasan tentang Undang-Undang Dasar Negara Indonesia) as follows:

Within the territory of the state of Indonesia exist more or less 250 [types of] "Selfgoverning villages" and Native communities such as desa in Jawa and Bali, negeri in Minangkabau, dusun and marga in Palembang, and so on. These areas have their own indigenous structures and, because of it, can be construed as areas with special attributes.

The State of the Republic of Indonesia respects the status of the said special areas and all the state regulations concerning them shall heed the original rights of these areas. ${ }^{61}$

\footnotetext{
${ }^{61} \mathrm{My}$ translation. In Indonesian the two quoted passages read: "Pembagian daerah Indonesia atas daerah besar dan kecil dengan bentuk susunan pemerintahannya ditetapkan dengan Undang-Undang, dengan memandang dan mengingati dasar permusyawaratan dalam sistim pemerintahan negara, dan hak-hak asalusul dalam daerah-daerah yang bersifat istimewa." "Dalam territoir negara Indonesia terdapat +1- 250 'Zelfbesturende landschappen' dan Volksgemeenschappen seperti desa di Jawa dan Bali, negeri di Minangkabau, dusun dan marga di Palembang dsb. Daerah-daerah itu mempunyai susunan asli, dan oleh karenanya dapat dianggap sebagai daerah yang bersifat istimewa. Negara Republik Indonesia menghormati kedudukan daerah-daerah istimewa tersebut dan segala peraturan negara yang mengenai daerah itu akan mengingati hak-hak asal-usul daerah tersebut." See A.M.W. Pranarka, Sejarah Pemikiran Tentang Pancasila (Jakarta: Centre for Strategic and International Studics, 1985), pp. 467, 473. The contradiction between the Village Law and the 1945 Constitution was pointed out to me by a prominent Indonesian intellectual whose name remains anonymous here.
} 